IRA-International Journal of Education \& Multidisciplinary Studies

ISSN 2455-2526; Vol.08, Issue 01 (July 2017)

Pg. no. $35-43$

Institute of Research Advances

http://research-advances.org/index.php/IJEMS

\title{
Use of Corporal Punishment in Relation to Institutional and Personal Variables of Teachers
}

\author{
Mamta Rani Garg \\ Assistant Professor, Department of Education, University School of Open Learning, \\ Panjab University, Chandigarh, India.
}

Type of Review: Peer Reviewed.

DOI: http://dx.doi.org/10.21013/jems.v8.n1.p5

\section{How to cite this paper:}

Garg, M. (2017). Use of Corporal Punishment in Relation to Institutional and Personal Variables of Teachers. IRA International Journal of Education and Multidisciplinary Studies (ISSN 2455-2526), 8(1), 3543. doi:http://dx.doi.org/10.21013/jems.v8.n1.p5

(C) Institute of Research Advances.

(cc) $\mathrm{EY}-\mathrm{NC}$

This work is licensed under a Creative Commons Attribution-Non Commercial 4.0 International License subject to proper citation to the publication source of the work.

Disclaimer: The scholarly papers as reviewed and published by the Institute of Research Advances (IRA) are the views and opinions of their respective authors and are not the views or opinions of the IRA. The IRA disclaims of any harm or loss caused due to the published content to any party.

Institute of Research Advances is an institutional publisher member of Publishers Inter Linking Association Inc. (PILA-CrossRef), USA. The institute is an institutional signatory to the Budapest Open Access Initiative, Hungary advocating the open access of scientific and scholarly knowledge. The Institute is a registered content provider under Open Access Initiative Protocol for Metadata Harvesting (OAI-PMH).

The journal is indexed \& included in WorldCat Discovery Service (USA), CrossRef Metadata Search (USA), WorldCat (USA), OCLC (USA), Open J-Gate (India), EZB (Germany) Scilit (Switzerland), Airiti (China), Bielefeld Academic Search Engine (BASE) of Bielefeld University, Germany, PKP Index of Simon Fraser University, Canada. 


\begin{abstract}
Corporal punishment is ingrained in schools worldwide as a normal disciplinary measure despite the legal ban on it in around 125 countries and India is one of these. Studies and media reports have shown a high prevalence rate (around 40\% to 99.9\%) across different parts of India. The unequal rate of punishment may be associated with school contexts. Therefore, it was intended to identify those institutional variables and teachers characteristics which determine the difference in the rate of use of corporal punishment. For this, data was collected from 202 teachers from 84 schools of Punjab. Results indicate that institutional variable such as school type, its location, organizational climate and personal variables of teachers, namely, their gender, marital status teaching experience, job satisfaction of teachers cause a difference in frequency of use of corporal punishment by teachers in schools. In this paper, the probable factors associated with these variables have also been explored.
\end{abstract}

\title{
INTRODUCTION
}

Around the world students are exposed to various forms of violence in the schools which include cruel and humiliating forms of psychological, physical, sexual and gender-based violence by pees as well as teachers (Plan International 2013). It creates insecurity and fear that works against the purpose of the school and goes against the rights of children. School violence thus has been considered as a serious issue worldwide.

Corporal Punishment was the first instance where the term "School Violence" was used. It is the punishments meted out to children by the teachers and school administration. Corporal punishment of students refers to intentional infliction of pain or discomfort and/or the use of physical force upon a student with the intention of causing the student to experience bodily pain so as to correct or punish the student's behavior (Bitensky, 2006). Though it mainly refers to physical pain either through hitting or forcing the child to sit /stand in uncomfortable positions; an evolving definition also includes within its ambit wrongful confinement, verbal insults, threats and humiliation, which are used with impunity and in utter disregard to the law of land and principles of learning. In a study on Indian schools, it was found that the most common forms of punishments are hitting with hands \& stick, pulling hair and ears, and asking the children to stand - for long periods - in various positions. Threatening to be physically violent is also used as a punishment to create fear among the children (Plan India, 2006). But corporal punishment does not mean physical violence on the child, but also verbal insults, humiliation and loss of self esteem (Protection of Children against Corporal Punishment in Schools and Institutions, 2008).

There are numerous cases where the teachers have been merciless in giving beatings and punishments which give severe psychological illness. Many children have been victims of such overboard punishments by teachers. Millions of children are physically abused, under the guise of discipline with a prevalence rate of even $80 \%$ in some countries despite the legal ban on corporal punishment in schools in more than 146 countries (Plan International Report, 2013). In India also, in different parts of country around $40 \%$ to $99.9 \%$ school children were punished in schools (Report on corporal punishment of children in India, 2015).

Punishments are mainly used by teachers to their students for their mistakes and rectify the undesirable behavior as per justifications of teachers. It is found that punishments are incurred for even relatively minor or nonviolent behaviors rather than safety-intimidating behaviors (Hyman \& Perone, 1988). It is general argument that children cannot be disciplined without punishment but there some teachers and principals had admitted that corporal punishment is not very effective (Little \& Akin- Little, 2008). Studies (Arif \& Rafi, 2007; Aucoin et al, 2006; Poole, et al, 1991) have reported that corporal punishment did not improve behavior but led to detrimental effects on children. Romi, Lewis, Roache, and Riley, (2011) found that in all cultures, teachers' aggressive management choices tended to increase the types of student misbehaviour they sought to diminish and generate negative feelings toward the teacher.

As evidenced punishment has a little role to modify the behavior of the students but it do have a lot of adverse effects. Mayer and Leone, (1999) posit that the coercive measures used by teachers on students interfere with their learning and result in an atmosphere of mistrust and resentment. Miller, Ferguson, and Byrne (2000) also reported that teacher behaviour such as shouting all the time, unfairly blaming students, picking on kids, and being rude, stimulate student resistance and subsequent misbehaviour. When the students have an early exposure to 
violence, it affects their physical and mental health. The adverse effects of corporal punishment is well proved which include lower school performance (Gul, Gulshan \& Ali, 2013); enhanced anxiety and aggression (Greydanus, 2010); adjustmental problems (Aucoin, Frick, \& Bodin, 2006); impaired mental health in future adult life (Gershoff, 2010) serious injuries, increased dropout rates etc (Human Rights Watch, 2008). Punishments on students not only affect psychological and educational development of students but also cause pro-violence attitudes among students (Gershoff, 2010; Wasef, 2011).

International studied have revealed the frequency of using corporal punishment differ according to school characteristics such as prevalence of minority and special need children (Gershoff \& Font, 2016; Gregory, 1995), school population (McClure \& May, 2008), school location and poverty (Nickerson \& Spears, 2007). Nickerson and Spears (2007) reported that school personnel in rural areas and those having a greater percentage of poor students were more likely to use corporal punishment whereas Tao (2015) attributed it to overcrowded classrooms and lack of in developing countries.

Many studies and reports have shown that corporal punishment is widespread in Indian schools despite legal ban on it and had even caused many unfortunate incidents of severe and sometimes fatal injuries. It is evidenced that frequent but unequal corporal punishment is levied against students in India but little is known about the school contexts associated with such unequal use. Thus it is important to understand contexts related with use of corporal punishment such as school characteristics and personal variables of teachers so that the customized measures may be adopted to reduce such punishment in schools.

\section{Objectives of the study}

The study aims at examining the relation of organizational variables, namely, type of school, locale of school, teacher-taught ratio and organizational climate with use of corporal punishment by teachers. Besides these, it is intended to see the relationship between personal variables of teachers such as gender, teaching experience, and job satisfaction with the rate with which they use corporal punishment in schools. Based on these aims, following objectives have been framed:

1) To see the difference in rate of corporal punishment inflicted by teaches in urban and rural schools.

2) To find out the difference in use of corporal punishment by teaches in government and private schools.

3) To compare the rate of corporal punishment by teachers w.r.t. to teacher-taught ratio in their classes (1:35 or more than this)

4) To find relationship of organizational climate of the school with use of corporal punishment by teachers.

5) To examine the gender differences in use of corporal punishment by teachers.

6) To investigate the difference in the rate of infliction of corporal punishment by married and unmarried teachers.

7) To study the correlation between rates of use of corporal punishment by teachers with their teaching experience i.e. number of years in teaching.

8) To see the relation of job satisfaction of teachers with their use of corporal punishment.

\section{METHODOLOGY:}

Descriptive survey method was used to investigate use of punishment by teachers in relation to institutional and their personal variables. To select the sample of teachers around 84 secondary schools from urban and rural areas of Punjab were selected which included both government/private schools. Because of legal ban on corporal punishment teachers in schools hesitated to give any information in first instance. After assuring the anonymity, about 202 school teachers agreed to participate in the study. To collect the data, a scale was developed which measured the frequency of use of the different types of punishments levied on students by the teachers. The total score on the scale was taken as the as the measure of punishing behavior of teachers. A personal data form was constructed to collect required personal and institutional information. Besides, Job satisfaction scale by Dixit (2008) and School organizational climate description questionnaire by Sharma (1998) were used to job satisfaction of teachers and their perception about school climate respectively. t-test and Product moment correlation were used to analyze the data.

\section{FINDINGS}

\section{Types of school and punishing behavior of teachers}

It was investigated whether the type of school i.e. government or private determine the rate of corporal punishment. For this, the data obtained from the teachers from government and private schools about the frequency of usage of punishments/aggression towards students were compared by using $\mathrm{t}$-test. The detail of which is given in table 1: 
Table 1: Significance of difference between punishing behavior of teachers of government and private schools:

\begin{tabular}{|l|l|l|l|l|l|}
\hline Type of school & N & Mean & S.D & S.E.D & t-value \\
\hline Government School & 104 & 9.89 & 2.34 & .311 & $\begin{array}{l}6.91 \\
\mathrm{p}<.01\end{array}$ \\
\cline { 1 - 4 } Private School & 98 & 7.74 & 2.1 & & \\
\hline
\end{tabular}

The t-value $(6.91, \mathrm{p}<.01)$ is significant thus implies that there exist a significant difference in the use of punishments by teachers of government and private schools. The higher value of mean for use of punishments of government school teachers (9.89) than private school teachers (7.74) indicates that government school teachers more often punish their students than their counterparts in private schools.

\section{Locale of School and Corporal Punishment}

To see the significance of difference in rate of inflicting punishments by teachers in rural and urban schools, t-test was employed (table 2):

Table 2: Significance of difference between punishing behavior of teachers of rural and urban schools

\begin{tabular}{|l|l|l|l|l|l|}
\hline Locale of schools & N & Mean & S.D & S.E.D & t-value \\
\hline Teachers in Rural Schools & 105 & 10.02 & 2.14 & .280 & $\begin{array}{l}8.96 \\
\text { p }<.01\end{array}$ \\
\cline { 1 - 4 } Teachers in Urban Schools & 97 & 7.69 & 1.86 & & \\
\hline
\end{tabular}

Significant difference is found $(\mathrm{t}=8.96, \mathrm{p}<.01)$ in the extent of use of punishments by teachers of schools located in rural and urban areas. Teachers from rural schools $(\mathrm{M}=10.02)$ become violent towards students more as compared to their counterparts in urban schools $(M=7.69)$. It entails that locale of the school also affect the behavior of the teachers towards students.

\section{Teacher-taught ratio and Rate of Corporal Punishment}

The data was obtained from the teachers about the number of students they had in their class. On the basis of this data, they were categorized into two groups, one who had 35 or less students in their class and another group of teachers who had more than 35 students in their class. t-test was used to difference in use of punishment by teachers with respect to the strength of their class i.e. teacher-taught ratio (table 3):

Table 3: Significance of difference between punishing behavior of teachers in relation to teacher-taught ratio of their classes

\begin{tabular}{|l|l|l|l|l|l|l|}
\hline Teacher-taught ratio & N & Mean & S.D & S.E.D & t-value & Remarks \\
\hline Up to $1: 35$ & 83 & 9.28 & 1.98 & .304 & 0.961 & $\mathrm{p}>.05$ \\
\hline More than 1:35 & 119 & 10.09 & 2.33 & & & \\
\hline
\end{tabular}

It is evident from the value of ' $t$ ' $(0.961, p>.05)$ that punishing behavior of teachers of more crowded $(>1: 35)$ and less crowded $(=$ or $<1: 35)$ classes do not differ significantly. It implies the number of students in a class do not affect the punishing behavior of teachers.

\section{Organizational Climate and Punishing behavior of teachers}

The relation of organizational climate with rate of punishment by teachers was assessed. For this, teachers were divided into two groups, one who perceived their schools climate as conducive and another groups of teachers who perceived their organizational climate as non-conducive and then difference between these two groups of teachers were seen by employing t-test. 
Table 4: Significance of difference between punishing behavior of teachers in relation to organizational climate

\begin{tabular}{|l|l|l|l|l|l|}
\hline Organizational Climate & $\mathrm{N}$ & Mean & S.D & S.E.D & t-value \\
\hline Conducive & 128 & 8.45 & 1.83 & .291 & $\begin{array}{l}2.51 \\
\mathrm{p}<.05\end{array}$ \\
\hline Non- Conducive & 74 & 9.18 & 2.12 & & \\
\hline
\end{tabular}

The ' $\mathrm{t}$ ' value $(2.51, \mathrm{p}<.05)$ indicate that a significant difference exist between teachers' punishing behavior in relation to their perceived organizational climate i.e. teachers who perceived their school climate as conducive inflict significantly lesser punishments on students $(\mathrm{M}=8.45)$ as compared to those who perceived their school climate as non- conducive. In other words it may be said that school climate is also a determinant of punishing behavior of teachers.

\section{- Personal Characteristics of Teachers and their Punishing Behavior Gender difference in use of punishment by teachers}

Table 5: Significance of difference in level of punishing behavior of female and male teachers

\begin{tabular}{|l|l|l|l|l|l|}
\hline Teachers & $\mathbf{N}$ & Mean & S.D & S.E.D & t-value \\
\cline { 1 - 4 } Female Teachers & 121 & 10.2 & 2.3 & \multirow{2}{*}{.285} & 9.19 \\
\cline { 1 - 4 } Male Teachers & 81 & 7.58 & 1.76 & & \\
\hline
\end{tabular}

The $t$ value $(9.19, \mathrm{p}<.01)$ point out that there exist a significant difference in the level of punishing behavior of male and female teachers in schools. The female teachers inflict punishment more frequently $(M=10.2)$ than their male counterparts $(\mathrm{M}=7.58)$.

\section{Marital Status of Teachers and their Punishing Behavior}

Table 6 Significance of difference in level of punishing behavior of married and unmarried teachers

\begin{tabular}{|l|l|l|l|l|l|}
\hline Groups of teachers & N & Mean & S.D & S.E.D & t-value \\
\hline Married & 123 & 7.389 & 1.53 & .264 & 10.57 \\
\cline { 1 - 2 } & 79 & 10.48 & 2.01 & & $\mathrm{p}<.01$ \\
\hline
\end{tabular}

e exist a significant difference in the extent of punishing behaviors of married and unmarried teachers as $\mathrm{t}$ came out to be significant $(\mathrm{t}=10.57, \mathrm{p}=.000)$. Unmarried teachers use punishment more frequently $(\mathrm{M}=10.48)$ as compared to the married teachers $(\mathrm{M}=7.39)$.

\section{Teaching Experience and Punishing Behavior of teachers}

Table 7: Correlation between teaching experience and punishing behavior of teachers

\begin{tabular}{|l|l|}
\hline Variables & Co-efficient of correlation (r) \\
\hline Punishing Behavior of teachers & $-0.234, \mathrm{p}<.05$ \\
\hline Teaching experience of teachers & \\
\hline
\end{tabular}

Negative correlation $(\mathrm{r}=-.0234, \mathrm{p}<.05)$ emerged between teaching experience and rate of use if punishments by teachers. It implies that with increase in teaching experience use of punishments by teachers on students decrease. In 
other words it may be said that novice teachers inflict punishments more often whereas experienced teachers mete out punishments less frequently.

\section{Teachers Job Satisfaction of teachers and their Punishing Behavior}

Product Moment co-efficient of correlation was worked out between frequency of incurring punishments on students by teachers and their score on job satisfaction. The value of co-efficient of correlation is given in table 8:

Table 8: Correlation between punishing behavior of teachers and their Job satisfaction

\begin{tabular}{|l|l|}
\hline Variables & Co-efficient of correlation $(\mathbf{r})$ \\
\hline Punishing Behavior of teachers & $-0.273, \mathrm{p}<.05$ \\
\hline Job Satisfaction & \\
\hline
\end{tabular}

Negative correlation came out between job satisfaction and punishing behavior of teacher $(r=-0.273, p<.05)$. It entails that with increase in level of job satisfaction among teachers, the frequency of incurring punishments by them decrease. It may be said that teachers with higher job satisfaction inflict lesser punishment and teachers with low level of job satisfaction use it more frequently.

After knowing that job satisfaction is one of the determinants of rate of use of corporal punishment by teachers, it was of interest to know the type of punishment being frequently used by teachers with low job satisfaction and those with higher job satisfaction. The findings have been presented in figure 1

\section{Figure 1 Different form of punishments used by teachers with low and high job satisfaction}

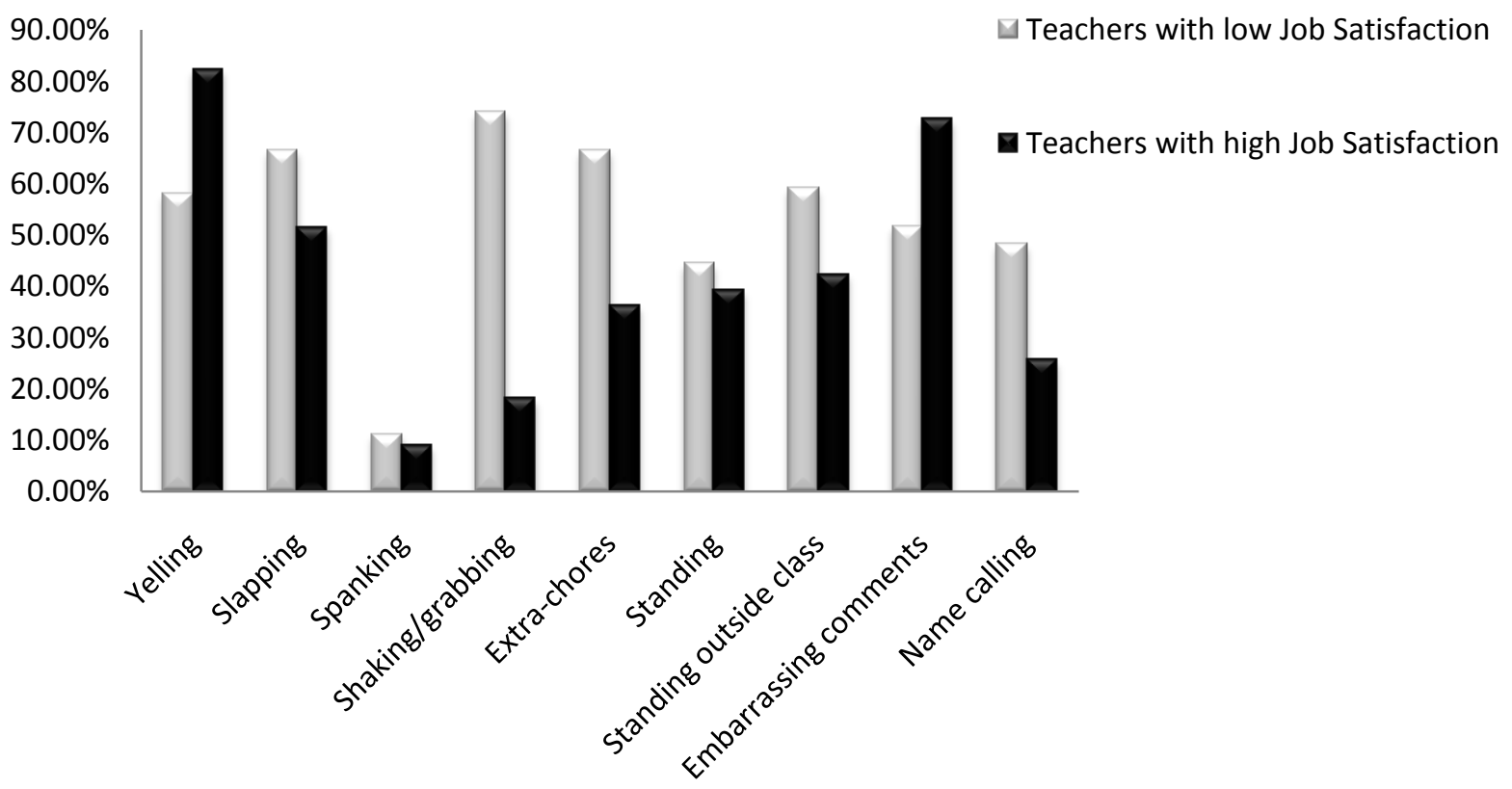

It is evident from the data given in figure 1 that except for yelling and passing embarrassing comments on the students, more teachers with low job satisfaction use punishments like slapping, grabbing/shaking, keeping students stand inside and outside the class, assigning extra chores, addressing them with hurting names and spanking than the number of teachers with higher job satisfaction used it. On the contrary the latter used yelling and passing embarrassing comments on students more than the former. In other words it may be said that though both the group 
of teachers use all the forms of punishments but the frequency of inflicting these as well as the number of teachers who used these vary with the level of job satisfaction. The teachers with low job satisfaction mete out physical punishments more often.

\section{DISCUSSION OF RESULTS AND IMPLICATIONS}

The results show that use of corporal punishment by teachers is related with both institutional and personal variables of teachers. The rate use of punishment is more in government schools and schools located in rural areas. Moreover, it was found that female teachers, less experienced teachers, unmarried teachers, less satisfied in job and who perceived their school climate as non-conducive inflict punishments on students more frequently than their respective counterparts.

With regards to institutional variables the findings of this study is consistent with other studies wherein it has been reported that corporal punishment was highest in areas that are rural, small, and have high proportions of low income or disadvantaged students (Han 2011; McClure \& May 2008; Nickerson \& Spears 2007). The sample of students taken from rural Punjab may be dominated by marginalized groups (Scheduled caste/ backward classes) as population of such students is higher than other categories in rural Punjab (Census, 2011). As far as government schools of urban areas are concerned, most of the students from economically weaker sections study in such schools. The parents of most of these disadvantaged groups of children are mostly Illiterate or less educated thus may not be able to fulfill their responsibility towards the education of their wards and left their wards on teachers. Due to lack of support from home these students may not be able to develop desirable educational behavior and due to lack of which they may be punished more frequently by their teachers. Owen (2005) also reported that rates of school corporal punishment are highest in regions of the country where residents report the strongest support for it. In India, the parents from low income group most of them reside in rural areas and send their wards in government schools may be condoning the punishment as also reported by Jain (2015) that parents in India condone corporal punishment as a disciplinary measure. Such schools lack of resources (especially insufficient staff) is said to be a reason for punishment (Hans, 2011). Moreover,

The relation of teachers' personal variables and their use of punishment may be understood in terms of Graziano and Linda (1992) who opine that a frequent punishment has more to do with a teacher's frustration level than with the child's misbehavior. As found in the present study teachers who had lower job satisfaction and perceived school climate as less conducive may have higher level of frustration with the system thus displace their frustration on students. Female, and novice teachers may be using punishment to control the class especially boys because they would not respect them without force (Proctor, 2015).

The uneven use of punishment may thus be due to lack of resources in schools, percentage of disadvantaged students lacking academic skills, acceptance of punishment parents, dissatisfaction among teachers and lack of skills as well as perceived notion of controlling the class among female teachers and also in novice teachers. These factors need to be explored further to ascertain its contribution towards use of punishment by teachers so that appropriate measures may be devised.

\section{Implications}

Corporal punishment is found to be deeply ingrained as a tool to discipline children and as a normal action in both government and private schools in rural and urban areas though with unequal spread. But all forms of corporal punishment breaches fundamental rights of children to lead a life of respect, dignity, and physical integrity. Thus it is necessary to eliminate it altogether. The schools should be provided with required resources and administrators as well as teachers have to change their attitude especially in government schools. The teachers have to understand that parents of disadvantaged students may not be able to help them in developing required skills and behavior thus they have to shoulder this responsibility themselves and patiently have to instill the desirable behavior among these students. The administrators should try to maintain a conducive climate in schools and ensure the job satisfaction of their teachers. The teachers should be trained in non-violent disciplinary measures. For this curricular in-service teacher training should be designed specifically on 'behavior modification techniques' and there is a need to add such topics in the curriculum of teacher education so that novice teacher would not resort to violent techniques to modify the behaviors of children. Besides these, all the stakeholders should keep this in mind that 
IRA-International Journal of Education \& Multidisciplinary Studies

violence breeds violence. Thus effective teaching and positive behavior management skills would help the teachers to "spare the rod" and help their students to learn without fear.

\section{Acknowledgement}

This study is a part of Major Research Project sponsored by University Grants Commission, New Delhi.

\section{REFERENCES}

1. Arif, M.S. \& Rafi, M.S. (2007). Effects of corporal punishment and psychological treatment on students' learning and behavior. Journal of Theory and Practice in Education, 3(2), 171-180.

2. Aucoin, K.J., Frick, P.J. \& Bodin, S.D. (2006). Corporal punishment and child adjustment. Journal of Applied Developmental Psychology, 27, 527-541. Retrieved from http://labs.uno.edu/developmentalpsychopathology/articles/JADP2006-corporal_punishment.pdf

3. Bitensky, S.H. (2006). Corporal punishment of children: A human rights violation. MSU Legal Studies Research Paper No. 04-04 . Available at SSRN:https://ssrn.com/abstract=929062.

4. Gershoff, E. T. (2010). More harm than good: A summary of scientific research on the intended and unintended effects of corporal punishment on children. Law and Contemporary Problems, 73(2), 31-56.

5. Gershoff, E.T. \& Font, S.A. (2016). Corporal punishment in U.S. public schools: Prevalence, disparities in use, and status in state and federal policy. Social Policy Report, 30(1). Retrieved from https://www.srcd.org/sites/default/files/documents/spr_30_1.pdf

6. Graziano, A. M., \& Linda J. (1992). Effects of corporal punishment on children. Violence Update, 86(3), 368-382.

7. Gregory, J.F. (1995). The crime of punishment: Racial and gender disparities in the use of corporal punishment in U.S. public schools. Journal of Negro Education, 64 (Autumn), 454-462.

8. Greydanus, D.E. (2010). Corporal punishment in schools and its effect on academic success. Retrieved from http://edworkforce.house.gov/uploadedfiles/04.15.10_greydandus.pdf

9. Gul, R., Gulshan \& Ali, A. (2013). Causes of dropout rate in government high schools (male). American International Journal of Research in Humanities, Arts and Social Sciences, 3(1), 120-125. Retrieved from http://iasir.net/AIJRHASSpapers/AIJRHASS13-223.pdf

10. Han, S. (2011). Probability of corporal punishment: Lack of resources and vulnerable students. The Journal of Educational Research, 104, 420-430. doi:10.1080/00220671.2010.500313.

11. Human Rights Watch, (2008). A violent education. Corporal punishment of children in US public schools. Retrieved from https://www.hrw.org/report/2008/08/19/violent-education/corporal-punishment-childrenus-public-schools

12. Hyman, I. A., \& Perone, D. C. (1998). The other side of school violence: Educator policies and practices that may contribute to student misbehavior. Journal of School Psychology, 36, 7-27.

13. Jain, M. (2015). Teachers are still using the stick in Indian schools and parents aren't doing anything to stop it. Retrieved from http://scroll.in/article/744492/corporal-punishment-is-still-rampant-in-indian-schoolsand-parents-arent-doing-anything-to-stop-it

14. Little, S.G. \& Akin-Little, A. (2008). Psychology's contributions to classroom management. Psychology in the Schools, 45(3), 227-234. doi: 10.1002/pits.20293.

15. Mayer, M.J., \& Leone, P.E. (1999). A structural analysis of school violence and disruption: Implications for creating safer schools. Education And Treatment of Children, 22(3), 333-356.

16. McClure, T. E., \& May, D. C. (2008). Dealing with misbehavior at schools in Kentucky: Theoretical and contextual predictors of use of corporal punishment. Youth \& Society, 39(3), 406-429.

17. Miller, A., Ferguson, E., \& Byrne, I. (2000). Pupils' causal attributions for difficult classroom behaviour. British Journal of Educational Psychology, 70 (1), 85- 96.doi: 10.1348/000709900157985.

18. Nickerson, A. B., \& Spears, W. H. (2007). Influences on authoritarian and ducational/therapeutic approaches to school violence prevention. Journal of School Violence, 6(4), 3-31. doi:10.1300/ J202v06n04_02.

19. Plan India (2006). Impact of corporal punishment on school children: A research study. Retrieved from https://www.planindia.org/download/file/fid/177\%20

20. Plan International and UNICEF (2010). Out of 10 kids in public elementary schools victims of violence. Retrieved from http://news.abs-cbn.com/lifestyle/08/10/10/7-out-10-kids-public-elem-schools-victimsviolence. 
21. Plan International Report (2013). The campaign to stop violence in schools. Third progress report. Retrieved from https://plan-international.org/learn-without-fear-third-progress-report\#download-options.

22. Poole, S. R., Ushkow, M. C., Nader, P. R., Bradford, B. J., Asbury, J. R., Worthington, D. C., et al. (1991). The role of the pediatrician in abolishing corporal punishment in schools. Pediatrics, 88, 162-167.

23. Proctor, Lavanya Murali (2015) "“Boys Must Be Beaten": Corporal punishment, gender, and age in New Delhi schools. Landscapes of Violence, 3(3). Retrieved from http://scholarworks.umass.edu/cgi/viewcontent.cgi?article=1040\&context=lov

24. Protection of Children against Corporal Punishment in Schools and Institutions (2008). Retrieved from http://harprathmik.gov.in/pdf/rte/corporal\%20punishment\%20ncpcr.pdf

25. Report on corporal punishment of children in India (2015). Global Initiative to End All Corporal Punishment of Children. Retrieved from www.endcorporalpunishment.org/assets/pdfs/statesreports/India.pdf

26. Romi, S., Lewis, R., Roache, J. \& Riley, P. (2011). The impact of teachers' aggressive management techniques on students' attitudes to schoolwork. The Journal of Educational Research, 104 (4), $231-240$. doi: 10.1080/00220671003719004

27. Tao, S. (2015). Corporal punishment, capabilities and well-being Tanzanian primary school teachers' perspectives. In J. Parkes (ed.) Gender violence in poverty contexts: The educational challenge. London: Routledge.

28. Wasef, N.H. (2011). Corporal punishment in schools. Master of Public Policy and Administration Thesis, The American University, Cairo. Retrieved from http://dar.aucegypt.edu/bitstream/handle/10526/1467/Corporal\%20Punishment\%20in\%20Schools.pdf?sequ ence $=1$ 